удК 339.9 (510)

Вэй Кэй

Байкальский государственный университет, г. Иркутск, Российская Федеращия

\title{
НАПРАВЛЕНИЯ РАЗВИТИЯ ВНЕШНЕЙ ТОРГОВЛИ РЕГИОНОВ СИБИРИ
}

\begin{abstract}
АннотАция. В настоящее время внешнеэкономическая деятельность сибирских регионов является решающим фактором развития производства и решения социальных задач по повышению уровня жизни населения в Сибири. Экономическая стратегия развития России и Сибири основывается на экстенсивном расширении экспорта энергоносителей за счет освоения новых месторождений и повышения мощностей действующих. В среднесрочной перспективе определяющее направление экспортной политики Сибири предполагает расширение сырьевого экспорта на Восток. Несмотря на резкие колебания объемов совместной торговли в целом в России за прошедшее десятилетие регионы Сибири резко увеличили суммарный объем экспорта в Китай. В результате возросло значение сибирского сектора в российско-китайской торговле. Из российских экспортеров на китайском направлении каждый второй был из Сибири. Сибирские регионы определяли не только объем и товарную структуру российского экспорта в Китай, но и выделялись среди субъектов Российской Федерации массовостью и высокой активностью фирм и предприятий-экспортеров.
\end{abstract}

кЛючЕВЫЕ СлОВА. Сибирь; внешнеэкономическая деятельность; внешняя торговля; Китай.

ИНФОРМАЦИЯ О СТАТЬЕ. Дата поступления 24 июля 2017 г.; дата принятия к печати 11 октября 2017 г.; дата онлайн-размещения 25 октября 2017 г.

Wei Kei

Baikal State University, Irkutsk, Russian Federation

\section{DIRECTIONS OF FOREIGN TRADE DEVELOPMENT OF SIBERIAN REGIONS}

\begin{abstract}
At the present moment, the foreign activity of Siberian regions is a decisive factor of production development and implementation of social objectives of increasing the social living standards in Siberia. The economic development strategy for Russia and Siberia is based on extensive expansion of energy resource export at the expense of developing new resource deposits and increasing power capacities of the existing ones. Over the medium term, the determining direction of Siberia's export policy assumes expansion of raw materials export to the East. Despite the violent fluctuations of the joint trade volume in Russia on the whole, during the past decade the Siberian regions have sharply increased the total volume of export to China. It has resulted in increasing the significance of the Siberian sector in Russo-Chinese trade. Of Russian exporters to the Chinese direction, each second was from Siberia. The Siberian regions determined not only the volume and commodity composition of the Russian export to China but they also stood out among the subjects of the Russian Federation by their large-scale participation and high activity of the companies and export businesses.
\end{abstract}

KEYWORDS. Siberia; foreign economic activity; foreign trade; China.

ARTICLE INFO. Received July 24, 2017; accepted October 11, 2017; available online October 25, 2017.

Основополагающей целью внешнеэкономической деятельности (ВЭД) сибирских регионов является прямое и опосредованное через развитие производства решение социальных задач по повышению уровня жизни населения в Сибири.

(C) Вэй Кэй, 2017

\section{Baikal Research Journal}


Вторая цель - обеспечение ресурсной и финансовой базы для решения экономических проблем страны, включая наполнение бюджета, погашение внешних и внутренних долгов, обеспечение валютных резервов [1, с. 49].

Сформулированные цели предопределяют необходимость повышения эффективности ВЭД и наращивания объемов торговли.

Выполнение поставленных условий требует:

1) совершенствования отраслевой и товарной структуры внешней торговли регионов, расширения географии торговли;

2) совершенствования государственного регулирования на всех уровнях (федеральном, региональном и муниципальном);

3) организации адаптированной к реальным текущим потребностям деятельности государственных служб по предоставлению регионам помощи в решении масштабных задач в области ВЭД;

4) введения персональной финансовой ответственности чиновников за принятие подзаконных актов, влекущих материальные потери участников ВЭД и наносящих ущерб государству;

5) организации практики отчетности в округах работников министерств, реально формирующих механизм регулирования и контроля ВЭД;

6) обеспечения прозрачности системы таможенного регулирования, определения законом обязательность чиновников предоставлять схему расчета таможенной пошлины заинтересованной стороне в случае возникновения спора [2, c. 269].

Во внешней торговле Сибири выделяются три направления: западное, восточное и страны СНГ и Балтия. Западное направление определено экспортом энергоносителей, на восточном направлении определяющее значение имеет металлургия и химия. Страны СНГ представляют основной для Сибири рынок сбыта готовой продукции машиностроения, стройматериалов, продукции сельского хозяйства и легкой промышленности [3, с. 3].

Экономическая стратегия развития России и Сибири основывается на экстенсивном расширении экспорта энергоносителей за счет освоения новых месторождений и повышения мощностей действующих. В среднесрочной перспективе определяющее направление экспортной политики Сибири предполагает расширение сырьевого экспорта на Восток. Оно включает создание энергетических мостов в направлении Юго-Восточной и Восточной Азии, чья суммарная потребность в импорте нефти оценивается в 480-570 млн т. в год.

Реализация поставок нефти и газа из Сибири по нефте- и газопроводам в восточном направлении обеспечит дополнительную степень свободы России на мировом рынке энергоносителей и послужит базой для экономического взаимодействия в других отраслях [4, с. 83].

Рост экспорта энергоносителей предусматривается в первую очередь в Китай и Монголию с дальнейшим выходом на остальные страны восточного региона. Необходимо рассчитать оптимальный для страны объем экспорта невозобновляемых ресурсов - нефти и газа - в рамках модели мирового производства и потребления энергоносителей. Оценка оптимума вывоза невозобновляемых ресурсов должна быть тесно увязана с оценкой объективного роста мировых цен по мере истощения доступных мировых запасов и возрастающего внутреннего спроса, в том числе в сибирских регионах-продуцентах.

Реализация стратегии связана с организацией необходимых транспортных коммуникаций, соединяющих восточные и западные регионы Сибири с Монголией и Китаем.

\section{Baikal Research Journal}

электронный научный журнал Байкальского государственного университета 


\section{Торговля регионов Сибири с Китаем: состояние и возможности.}

Экспорт Сибири в Китай.

Несмотря на резкие колебания объемов совместной торговли в целом в России за прошедшее десятилетие регионы Сибири резко увеличили суммарный объем экспорта в Китай. В результате возросло значение сибирского сектора в российско-китайской торговле. Из российских экспортеров на китайском направлении каждый второй был из Сибири. Сибирские регионы определяли не только объем и товарную структуру российского экспорта в Китай, но и выделялись среди субъектов Российской Федерации массовостью и высокой активностью фирм и предприятий-экспортеров [5, с. 268].

Центр экспортной деятельности переместился в Восточную Сибирь, которая обеспечила почти 56 \% стоимости экспорта. Для некоторых регионов Восточной Сибири поставки в Китай стали определяющими во внешней торговле, и особенно в сибирских регионах, имеющих общую границу с Китаем. Так, на Китай приходилось свыше 60 \% всего регионального экспорта Бурятии и Забайкальского края, свыше $23 \%$ - Иркутской области. В целом квота Китая в экспорте Восточной Сибири поднялась до $13 \%$. При этом в экспорте Западной Сибири она опустилась до $4,5 \%$, в результате экспорт в Китай остался на низком уровне и в целом для Сибири - его доля составляла лишь 7 \% от стоимости всех продаж Сибири на внешнем рынке в 2015 г.

Сравнение показателей торговли с Китаем регионов Западной Сибири с регионами Восточной позволяет оценить важность наличия прямых переходов общей границы, в первую очередь - автомобильных [6, с. 110].

Экспорт Сибири в Китай в 2015 г. включал товары 867 наименований. Это достаточно широкий спектр товаров, но основное их количество представляло мелкие партии. Среди них выделяются 38 товаров, которым соответствовали поставки стоимостью свыше 5 млн дол. и которые в сумме обеспечили $95 \%$ всего экспорта в Китай. Так, 25 \% стоимости представлял алюминий необработанный, около $64 \%$ - лес и лесоматериалы, черные металлы, целлюлоза, картон и продукты химии, около $5 \%$ - продукты машиностроения (в основном авиастроения).

Многие грузы могут быть вывезены автомобильным транспортом. Для дальнейшего роста торговли существуют объективные предпосылки. Сопоставление структуры встречных товаропотоков по отраслевому признаку показывает, в какой степени они дополняют друг друга. Все отрасли распадаются на 2 группы. В экспорте Сибири лидирующими являются цветная, черная металлургия, химическая отрасль и лесопромышленный комплекс. В импорте - товары топливно-энергетического комплекса за счет поставок кокса и пека для цветной металлургии в Сибирь, товары легкой промышленности и машиностроительной отрасли. $\mathrm{K}$ этой же группе относятся также сельское хозяйство, пищевая промышленность и строительный комплекс. Что касается химического комплекса, то его продукцию, скорее, можно отнести к поставляемой в Китай, нежели к ввозимой. Сальдо по этой группе товаров составляло 307 млн дол. в пользу Сибири [7, с. 44].

За прошедший период структура поставок изменилась в связи с некоторым сокращением доли черных металлов. Вывоз сырья и материалов из Сибири в Китай продолжает оставаться определяющим, а спрос на многие сибирские товары постепенно будет перемещаться из восточной части Китая в западную - в соответствии с распространением экономических преобразований в китайской экономике. Пока же все грузы в Китай (в том числе Западный) в основном ввозятся через восточный участок границы.

Всего всеми видами транспорта через южные таможни Западной Сибири (без Тюменской области) в направлении стран Средней Азии, Казахстана, Китая и

\section{Baikal Research Journal}

электронный научный журнал Байкальского государственного университета 
Монголии прошло 3,3 млн т. груза на сумму 671 млн дол., при этом по железной дороге отправлено грузов в 36 раз больше, чем на автомобилях. Автомобильный транспорт использовался относительно мало, по объемам перевезенных грузов он находился на 3-м месте после железной дороги и стационарного транспорта. Доля автомобильного транспорта в обслуживании торговли с Китаем с запада остается ничтожно малой.

\section{Импорт Сибири из Китая.}

В 2015 г. сократился ввоз в Россию из КНР продовольственных товаров и более чем на 56 \% вырос импорт товаров народного потребления (изделия из кожи, обувь, текстиль, трикотаж). В 6 раз увеличился импорт машин и оборудования. Основным каналом поступления китайского ширпотреба в Россию остаются чартерные авиарейсы. По данным китайской стороны, ими ввозится в Россию товаров на сумму более 9 млрд дол.

Основной поток товаров из Китая в Россию был направлен на Москву и Московскую область и достигал $40 \%$ всего российского импорта из Китая, на Сибирь приходилось лишь $22 \%$, на Дальний Восток - менее 18 \% . Доля Китая в полном импорте Сибири остается незначительной - всего 5,8 \% его стоимости. Для восточной части Сибири она равнялась $8,1 \%$, для западной $-3,8 \%$ [5, с. 319].

Среди западно-сибирских регионов по ввозу китайских товаров выделяется Новосибирская область - современный быстро растущий центр финансовой и деловой активности в Сибири. В восточной части лидируют Иркутская область, Красноярский край и Республика Хакасия, в структуре ввоза которых определяющее место занимает сырье для алюминиевой промышленности. На три крупнейших предприятия цветной металлургии (ОАО «Красноярский алюминиевый завод», АООТ «Братский алюминиевый завод», ОАО «Объединенная компания Сибирский алюминий») приходилось свыше $41 \%$ всего импорта Сибири из Китая. Регионы, в импорте которых доля китайских товаров относительно высокая - Алтайский край, Забайкальский край, Республика Бурятия - но это приграничные территории с относительно низким уровнем торговли на внешнем рынке. В импорте крупных сибирских партнеров - Иркутской, Кемеровской и Новосибирской областях - импорт китайских товаров составляет около $7 \%$ [4, с. 85].

Приведенная статистика не учитывает внутреннее перемещение китайских товаров в стране. Следует отметить значительную разницу между статистически зафиксированным ввозом и реальным потреблением китайских товаров в Сибири. Ввоз китайских товаров, особенно товаров народного потребления, преимущественно проходит через Москву и Московскую область, оттуда товары развозятся по стране, в том числе часть из них перемещается на рынки сибирских регионов. Эта тенденция возросла в 2001 г. после решения ГТК закрыть часть таможенных пунктов в Сибири для китайских товаров в целях усиления контроля за ввозом импорта из Китая. Для Сибири негативным следствием этой меры явилось удорожание китайских потребительских товаров массового спроса [7, с. 48].

Эффективность импорта упала, и количество импортеров на китайском направлении сократилось до 531 , что в 3 раза меньше числа экспортеров. В основном они сосредоточены в Забайкальском крае и Иркутской области. В некоторых сибирских регионах на китайский рынок выходило менее 10 фирм.

Государственных структур среди импортеров было всего 27 , основную массу составляли акционерные общества и общества с ограниченной ответственностью (292), а также частные предприниматели (197). В Сибири появились и действуют успешно первые пока немногочисленные китайские специализированные торговые фирмы. Грузы из России на Китай в основном идут через граничные переходы Восточной Сибири, но это на 80 \% товары Сибири.

\section{Baikal Research Journal}

электронный научный журнал Байкальского государственного университета 
Благоприятные условия для экспортной деятельности, сложившиеся в России, повлекли резкую интенсификацию экспорта по товарам экспортной специализации Сибири - металлы, лес и продукты деревопереработки, химия и нефтехимия. Ведущим товаром стал алюминий необработанный. В структуре экспорта в Китай появились продукты нефтепереработки. Хотя в целом, сложился дисбаланс экспорта и импорта из Китая. «Стоимость экспортируемой КНР продукции машиностроения и приборостроения в 2006-2009 гг. оценивалась более чем в 780 млрд дол., что в несколько раз больше стоимости экспорта всех углеводородных ресурсов России (для сравнения: стоимость экспортируемой Россией сырой нефти в 2008 г. составляла 152 млрд дол.» [8, с. 138].

Интенсивное развитие западного Китая и выход из кризиса сибирских регионов при условии создания необходимой инфраструктуры открывает новые возможности роста межрегионального товарообмена. Сюда относятся объекты приграничной торговли, создание СЭЗ и СТЗ и др.

\section{Список использованной литературы}

1. Лунев С. Чего стоит Сибирь / С. Лунев // Международные процессы. - 2004. T. 2, № 1. - C. 110-114.

2. Ларин В. Л. Российско-китайские отношения в региональных измерениях (80-е годы XX - нач. XXI в.) / В. Л. Ларин. - М. : Восток-Запад, 2005. - 390 с.

3. Дубнов А. П. Сибирь в геополитических теориях: благо, бремя, зло для России / А. П. Дубнов // Регион: экономика и социология. - 2006. - № 1. - С. 3-18.

4. Ковалева Г. Д. Концепция развития внешнеэкономической деятельности Сибири / Г. Д. Ковалева // Регион: экономика и социология. - 2006. - № 2. - С. 82-92.

5. Субъекты Федерации и города Сибири в системе государственного и муниципального управления / под ред. А. С. Новоселова. - Новосибирск : Изд-во ИЭОПП СО РАН, 2005. $-420 \mathrm{c}$.

6. Пойкер М. Б. Торговая политика России в отношении древесины и изделий из неё / М. Б. Пойкер // Российский внешнеэкономический вестник. -2013. - № 9. - С. 41-78.

7. Рогачев И. Российско-китайское межрегиональное и приграничное сотрудничество / И. Рогачев // Международная жизнь. - 2005. - № 11. - С. 43-53.

8. Цвигун И. В. Тенденции развития внешнеэкономической деятельности КНР / И. В. Цвигун, Я. А. Суходолов // Известия ИГЭА. - 2010. - № 2. - С. 135-141.

9. Статистический ежегодник Забайкальского края. 2012 : стат. сб. / Забайкалкрайстат. - Чита, 2015. - 320 с.

10. Суходолов А. П. Байкальский регион как модельная территория устойчивого развития / А. П. Суходолов // Известия ИГЭА. - 2010. - № 4. - С. 103-108.

\section{References}

1. Lunev S. What does Siberia cost? Mezhdunarodnye protsessy = International processes, 2004, vol. 2, no. 1, pp. 110-114. (In Russian).

2. Larin V. L. Rossiisko-kitaiskie otnosheniya v regional'nykh izmereniyakh (80-e gody $X X-$ nach. $X X I$ v.) [Russo-Chinese relations in regional measurements (80-s of XX - early XXI centuries)]. Moscow, Vostok-Zapad Publ., 2005. 390 p.

3. Dubnov A. P. Siberia in geopolitical theories: the good, the burden and the evil for Russia. Region: ekonomika $i$ sotsiologiya $=$ Region: Economy and Sociology, 2006, no. 1, pp. 3-18. (In Russian).

4. Kovaleva G. D. Concept of Siberia's foreign activity development. Region: ekonomika i sotsiologiya = Region: Economy and Sociology, 2006, no. 2, pp. 82-92. (In Russian).

5. Novoselov A. S. (ed.). Sub" ekty Federatsii i goroda Sibiri v sisteme gosudarstvennogo $i$ munitsipal'nogo upravleniya [Subjects of Federation and Siberian towns in system of governmental and municipal management]. Novosibirsk, Institute of Industrial Production Economy and Management of SB RAS Publ., 2005. 420 p.

\section{Baikal Research Journal}


6. Poiker M. B. Russia's trade policy with regard to timber and wooden products. Rossiiskii vneshneekonomicheskii vestnik = Russian Foreign Policy Bulletin, 2013, no. 9, pp. 41-78. (In Russian).

7. Rogachev I. Russo-Chinese inter-regional and cross-border cooperation. Mezhdunarodnaya zhizn' = International Life, 2005, no. 11, pp. 43-53. (In Russian).

8. Tsvigun I. V., Sukhodolov Ya. A. Tendencies of foreign economic activity development in PRC. Izvestiya Irkutskoi gosudarstvennoi ekonomicheskoi akademii = Bulletin of Irkutsk State Academy of Economics, 2010, no. 2, pp. 135-141. (In Russian).

9. Statisticheskii ezhegodnik Zabaikal'skogo kraya. 2012 [Statistical Yearbook of Zabaikalye Territory]. Chita, Zabaikalkraistat Publ., 2015. 320 p.

10. Sukhodolov A. P. Baikal region as a model territory of stable development. Izvestiya Irkutskoi gosudarstvennoi ekonomicheskoi akademii = Izvestiya Bulletin of Irkutsk State Academy of Economics, 2010, no. 4, pp. 103-108. (In Russian).

\section{Информация об авторе}

Вэй Кэй - аспирант, Байкальский государственный университет, 664003, г. Иркутск, ул. Ленина, 11, e-mail: keyi0073952@163.com.

\section{Author}

Wei Kei — PhD Student, Baikal National University, 11, Lenin str., Irkutsk, 664003, e-mail: keyi0073952@163.com.

\section{Для цитирования}

Вэй К. Направления развития внешней торговли регионов Сибири / К. Вэй // Baikal Research Journal. - 2017. - T. 8, № 3. — DOI : 10.17150/2411-6262.2017.8(3).6.

\section{For Citation}

Wei K. Directions of foreign trade development of Siberian regions. Baikal Research Journal, 2017, vol. 8, no. 3. DOI: 10.17150/2411-6262.2017.8(3).6. (In Russian).

\section{Baikal Research Journal}

